\title{
GENDER DIFFERENCES OF ELEMENTARY LEVEL L2 LEARNERS
}

\author{
Gharizi Matiini \\ Institut Teknologi Indonesia \\ email: gharizi.matiini@iti.ac.id
}

\begin{abstract}
The study aims to seek the difference of language abilities between male and female young learners. Previous studies have already given plenty of evidence that there are some boundaries between male and female language learners in achieving language ability. However, there are only a few studies that look into gender differences of language ability in younger L2 learners. The present study used two young learners as the participants and the data was collected only in spoken language. Therefore, the data analysis only focused on the verbal ability and the use of a linguistic device. The study found that male learner was more fluent in speaking L2 than the female one. He produced more words and used more sentence conjunctions than the female learner did. He also talked more smoothly and in more details than the female learner. However, both learners were equal in using intensifiers. In conclusion, though many studies stated that female learners master L2 more quickly than male learners, it might be different when it comes to the younger level L2 learners. Here, both male and female learners have a balance level of ability of L2 learning.
\end{abstract}

Keywords: gender difference, young L2 learner, language ability

\section{PERBEDAAN JENIS KELAMIN PADA PEMBELAJAR BAHASA ASING USIA MUDA}

\begin{abstract}
Abstrak
Penelitian ini bertujuan untuk mengidentifikasi perbedaan kemampuan berbahasa Inggris antara siswa bahasa level dasar dasar laki-laki dan perempuan. Penelitian sebelumnya telah banyak membuktikan bahwa ada beberapa perbedaan antara siswa lakilaki dan perempuan dalam menguasai kemampuan bahasa. Namun, hanya sedikit penelitian yang fokus pada kemampuan bahasa kedua di antara siswa tingkat dasar. Penelitian ini menggunakan dua siswa sekolah dasar sebagai partisipan dan bentuk data yang diambil berupa rekaman berbicara mereka. Dengan terbatasnya bentuk data, analisis penelitian ini hanya fokus pada kemampuan verbal dan penggunaan perangkat linguistik. Hasilnya menujukkan bahwa siswa laki-laki mampu menguasai kemampuan berbicara bahasa kedua daripada siswa perempuan. Siswa laki-laki menghasilkan lebih banyak kata-kata serta kalimat penghubung. Dia juga berbicara lebih lancar dan detil ketimbang siswa perempuan. Namun, kedua siswa tersebut seimbang dalam penggunaan Intesifier. Sebagai kesimpulan, meskipun banyak penelitian yang membuktikan
\end{abstract}


bahwa siswa perempuan mampu menguasai bahasa kedua lebih cepat ketimbang siswa laki-laki, masih ada kemungkinan berbeda jika mereka adalah siswa level dasar. Dalam penelitian ini, keduanya sama-sama memiliki kemampuan yang seimbang dalam menguasai bahasa kedua.

Kata Kunci: perbedaan gender, pembelajar L2 pemula, kemampuan berbahasa

\section{INTRODUCTION}

A great number of studies (Lakoff, 1975; Holmes, 2001; Coates, 1997; Tannen, 2007) were conducted in the field of gender difference and they resulted to the varieties characteristics of gender language. The results commonly focused on the linguistic devices (Holmes, 2001; Tannen, 2007), language production strategies (Zimmermen \& West, 1975; Coates, 1997), and verbal abilities (Kimura, 2006). However, most of the studies emphasized their data only at the gander in general without looking at the different age or education level.

There are few studies investigated the gender difference of the language learners. Yet, it is still rare to find the studies of gender difference in young learners. Some authors such as Gascoigne, (2002); Gallego, (2012); Shakouri, (2012) are few of the researchers who had successfully discovered that different gender of language learners have different characteristics in producing the language. The language of learners is a bit different with the language of adults since the learners are still in the middle of developing their language. Moreover, Gallego (2012) found that gender is one of the most relevant factors used in SLA research to distinguish among the learners (p. 47). Thus, researchers take the gender difference in- to the consideration when conducting the language use of the learners.

However, examining the language use of the learners using gender difference could also be problematic for the researchers as the learners are still developing their language. Jiménez (2003) and Young \& Oxford (1997) stated that gender difference studies usually indicate contradictory findings, and therefore, reach different conclusions. Some researchers believed that female learners achieve better proficiency in learning a language while others said the other way around. Therefore, investigating the language difference of the learners from the point of view of gender is always interesting to be conducted.

The present research aims to investigate the gender difference of the elementary level students in producing the language. In particular, the study focuses only on finding the difference of the young learners' languages in the spoken situation. The research question of the case study is written as follow: to what extend does the difference of language use between young male and young female learners exist?

The study emphasizes the spoken language produced by the learners. Moreover, the study only provides two different kinds of spoken language data, peer 
conversation and telling a narrative text. The peer conversation is used to find the gender difference in interaction, while the narrative is applied to discover the gender difference in monologue text.

Numbers of characteristics of gender difference of the learners had been identified in many areas of language use. One of them is from the classroom interaction where the learners express and share their knowledge with their teachers and classmates. Therefore, there are many kinds of language use applied by the learners. "Studies of classroom interaction have long shown that boys tend to dominate classroom interaction" (Gascoingne, 2002:83). Thus, teachers and educators usually provide extra time for the boys to talk in the classroom. Swan (Gascoingne, 2002:83) also stated that "in contrast to the stereotype of the overtalkative women...it is men who dominate the talk...men have been found to use more interruptions... and simply to talk more than women" (Gascoigne, 2002:83). Interrupting talk is one of the ways of boys to dominate the classroom interaction.

On the other hand, Girls tend to talk less in the classroom; however, it does not mean that girls do not like to talk much in the classroom. Niyikos (1990) reports "female students seek social approval more than male students" (Aslan, 2009:55). Girls commonly talk when they have the permission from the interlocutors to talk, and thus, they often lost out when they converse with the boys. Holmes (2001) explained that the politeness of the girls during the conversation makes them disadvantaged in the midsex classroom (Gascoigne, 2002:203).
To be inferred, male learners commonly talk more than the female learners. Through interruption, boys defeat the girls' talk and dominate the classroom. Consequently, teachers tend to only focus on the boys behavior rather than the girls during the class.

In terms of grammar and vocabulary production, both genders have different abilities when they talk. Male learners are usually prominent in producing vocabulary in foreign language (Edelenbos \& Vinjé, 2000). Therefore, when they speak in a foreign language, boys tend know unfamiliar words and expressions more than the girls.

On the contrary, "girls usually use longer sentences. Their articulation and grammar are more correct. Consequently, they have a richer vocabulary" (Piasecka, 2010:146-149). For that reason, girls are commonly more successful in doing language test than the boys particularly in reading and grammar tests.

The linguistics device in the field of gender difference is any ways of the speakers to express their thought and opinion towards the interlocutor so that the interlocutor not only understand but is also being interested with what the speaker or the writer says. Here, Gascoigne (2002), in his study on "the Role of Gender in L2 Interaction: Socialization via L2 Materials" brings that males when producing the language tend to use linguistic devices such as interruptions, directives, and sentence-initial conjunctions (Gascoigne, 2002:83). In the classroom interaction, boys like to interrupt the conversation and so that, dominate the classroom talk. They are also being directive in expressing their opinion and 
thus, direct sentences are very common used by the boys. Lastly, when starting the speech, boys use more conjunctions than the girls (Gascoigne, 2002:83). Conjunctions such as because, although, and, etc. are usually put in the beginning of their utterances.

Females, on the other hand, commonly use justifiers, intensive adverbs, personal pronouns and word-initial adverbs (Gascoigne, 2002:83). In their talk and writing, girls like to use any kinds of connectors that can justify their arguments. Justifiers such as "indeed, in fact, again, etc." are likely to be used by the girls than the boys. Girls also like to use intensive adverbs to emphasize their thought such as "very, really, so, terribly, etc." Lastly, word-initial adverbs such as "obviously, usually, etc." are commonly put in the beginning of their utterances. They like to use those adverbs rather than the boys.

Studies of gender difference in young learners have shaped to the varieties of conclusions about the major characteristics of the learners in producing the language. Ellis (1994) in his book "Second Language Acquisition" stated that there was nothing conclusive in studies of gender differences in SLA achievement, attitudes and strategy use. His study of gender difference in second language learners inferred that there will be always different results and findings when it comes to investigate the learners' language characteristics based on the gender. Moreover, Gallego (2012) in his study of Primary and secondary EFL students in vocabulary development found that male and female learners display similar be- haviors in lexical learning. Since young learners are in their time to acquire their language proficiency, there is always possibility of the learners to have similar characteristic in their language learning before they reach their perfect abilities in producing the language. Finally, Shakouri (2012) in his study of finding the age and gender influence in L2 acquisition discovered that both males and females are equipped with some predetermined tendencies that would be helpful for them to acquire some aspects of language much faster and easier. Both female and female learners of L2 have their own strengths that eventually help them to learn L2.

The earlier studies above have proven that investigation of gender difference in language learners particularly the young learners have not reached the fixed results since the learners language are dynamic and can be changed over the period.

\section{METHOD}

Two students of the fifth grade in an elementary school were chosen as the participants of the study. They consist of one female and one male student. They are both classmates in a bilingual class of a private school in Jakarta. The data were taken place in two different days, in the forth and seventh of April 2014. It happened because when the first data were taken, it was considered that the data would not be sufficient to be analyzed as it was only in the form of dialogue. For that reason, the second data were taken in the form of monologue.

The data were collected trough recording the participants' spoken language 
in two ways, peer dialogue, and monologue. The peer dialogue was taken from the conversation they built using two given topics, school uniform and the difference between boys and girls. In the conversation, they were asked to have their own opinion about the topics. Their opinion must have been different to each other so that the conversation was more likely to be a debate than a usual conversation. On the other hand, the monologue was shaped from telling a narrative story using a narrative driven picture. Both participants were asked to tell a story about daily life based on the picture given. Instead of telling the story together, the participants were being separated when they did the monologue so that there was no interruption from other participant when the monologue was taken.

The case study was used in this research as it only used two participants as the data source. Both quantitative and qualitative analyses were executed in the study. Computational analysis tool was used to analyze the data quantitatively, while categorization and interpretation would be used to examine the qualitative results.

After transcribing and encoding the data, the study analyzed the gender difference in the participants' language used through several ways. First of all, their language productions were categorized based on their frequency of use using Paul Nation's (1984) Range program. It is a program that counts the frequency of a text and matches it with the word bases categorization. There are tens of word base files in the program that includes tens thousands of token or running words. The very beginning of the word base files includes the most frequent running words and the last word base files are the least frequent running words. From using the range program it can be known which word bases that the participants mostly produced.

Another way of analyzing the data was from categorizing the code using the three categories, the vocabulary, the grammar used, the strategy used of turn taking, and the linguistic devices to ease the conversation.

\section{FINDINGS AND DISCUSSION Result}

The section contains the results from the analysis of gender difference in young learners. In these findings, the characteristics of code switching were discovered using several ways of analysis.

The study found that male learner was more fluent in speaking L2 than the female one. He produced more words and used more in sentence conjunction than the female learner did. He also talked smother and more detail than the female leaner. However, both learners were equal in using intensifier. To be concluded, though many studies stated that female learners master L2 quicker than male learner, it might be different when it comes to the younger level L2 learners. Here, both male and female learners had balance level of ability of L2 learning.

\section{Discussion \\ Gender Difference in Classroom Interaction (Dialogue)}

The data of the classroom interaction were gathered from the peer dialogue ex- 
ecuted by the participants. The result of this section was analyzed in two ways, by counting the sum of the words produced the participants to find which learner dominates the interaction and by categorizing the take turn strategy applied by the participants.

From the counting words analysis, it is found that the male learner produced more words that the female learner. The boy produced 294 words while the girl had 174 words. Beside words production, the male participant produced more words in each sentence than the girl and made him constructed longer sentences than the girl.

In the case of take turn strategy, boys tended to interrupt the girl's talk more than the girl. Meanwhile, the female participant talked when it was the time for her to talk, which is when the boy stopped talking.

Example:

F : Oooh. (laugh) because Matthew is so weird and there ...

$\mathrm{M}$ : Because Purple is so strange.

$\mathrm{F}$ : Boys are more disgusting than ...

M : Girls are too chatty and they like to blablabla, cosmetic, blablabla make up, and blablabla things.

F : I don't like ...

$\mathrm{M}$ : And money.

F : I don't like make up.

From the results above, it can be inferred that boys dominated the interaction than the girl. It was seen from the sum of the words and the interruption made by the boy which had more than the girl. The findings support the argument from Gascoingne (2002, p. 83) who claimed that boys tend to dominates the classroom interaction. The agreement also occurs with the statement from Niyikos (1999) that the girls, when they try to talk, usually need the approval from the interlocutor to talk. Therefore, when the girls talk with the boys, it would be obvious that the girls talked less than the boys.

\section{Gender Difference in Verbal Abilities (Monologue and Dialogue)}

The data of the participants' verbal abilities were gathered from the narrative story telling based on the picture executed by the participants. The result of this section was analyzed in two ways, by counting the words and using the Range program of Paul Nation (1984) to seek the vocabulary knowledge of the participants, and from analyzing the linguistic devices applied by the participants.

In the monologue text, the male participants told longer story than the girls. It can be seen from the sum of the words produced by the male learner was more than the female learner with 185 words while the girl with 115 words. Moreover, the boys told the story in more detail than the girl. He tended to extend his utterances with describing every thing in detail such as mentioning the name of the food for breakfast and dinner, naming the bird, and explaining the kinds of plays in the playground. On the other hand, the girl described the story with more direct and consistent sentences. It makes her produced the words less than the boy. 
Table 1 Examples of Monologue Utterances.

\begin{tabular}{ll}
\hline Male & Female \\
\hline $\begin{array}{l}\text { At seven o' clock she eats dinner. She usually } \\
\text { eats egg and sausages. }\end{array}$ & At seven o'clock he eat breakfast. \\
$\begin{array}{l}\text { And after that she feed the bird, she feed her } \\
\text { bird. Her bird's name is Spocky. It is a parrot. }\end{array}$ & And ... feed the bird. \\
$\begin{array}{l}\text { At seven o' clock she eats dinner. She usually } \\
\text { eats egg and sausages. }\end{array}$ & At seven o'clock he eat breakfast. \\
$\begin{array}{l}\text { And after that she feed the bird, she feed her } \\
\text { bird. Her bird's name is Spocky. It is a parrot. }\end{array}$ & And ... feed the bird \\
$\begin{array}{l}\text { At seven she eats dinner. She ... she loves to } \\
\text { eat broccoli and ham }\end{array}$ & At seven o' clock ... he eat his dinner. \\
\hline
\end{tabular}

On the contrary, the range program gave the distinct result from the sum of the words result. The result revealed insignificant differences of the range words they produced. while the unfamiliar words proved that the speakers know the unfamiliar words which are not really common used by the other speaker. In this case the male participant was able to use the familiar words

Table 2. The result of Nation's (1984) Range program

\begin{tabular}{|c|c|c|}
\hline Baseword & Male & Female \\
\hline $\begin{array}{l}\text { Baseword } 1 \text { (conj, prep, pro, and common } \\
\text { words) }\end{array}$ & $82.54 \%$ & $81.42 \%$ \\
\hline Baseword 2 (common words) & $11.64 \%$ & $15.04 \%$ \\
\hline Baseword 3 (common words) & - & $0.88 \%$ \\
\hline $\begin{array}{l}\text { Not in the list (proper name, compound } \\
\text { words) }\end{array}$ & $5.82 \%$ & $2.65 \%$ \\
\hline
\end{tabular}

It can be seen from the table that the male participant produced the words up to the word base 3 while the girl reached the word base 2 which means both participants produces mostly common words during the time. The male participant made more words in word base 1 with $82,5 \%$ while the female participant used word base 2 more than the boy with $15 \%$. Interestingly, both learners also produced the words which are not included in the word based, the unfamiliar words. Here, the boy constructed more words that the girl with $5,8 \%$. The use of conjunction all the time could ease the hearer to understand the flaw of the speakers' talk, as well as the unfamiliar ones more than the girls. However, the male counting was not really significant with the female participant as the girl's talk was at almost the same degree of counting with the boy's talk.

The result of the words counting argues the statement from Kimura (2006) who claimed that girls use longer sentences than the boys. In fact, the young male learner happened to use longer sentences than the female one. In contrast of Kimura's argument, the finding actually supports the theory of Edelenbos \& Vinjé (2000) who stated that boys have more knowledge in foreign language than the 
girls. Here, the boy produced more unfamiliar words such as compound words and proper names than the girl.

In the dialogue result, as mentioned before, the boy had more words and created longer sentences than the girl. The boy, with 294 words exceeded the girl's talk which has only 174 , half of what the boy produced. The result also argues what Kimura (2006) stated that the girl use longer sentence than the boy. The boy also had richer vocabulary than the girl as it was seem in the result of the Range program that the boy produced more words in word base 1 and three. Thus the result broke Kimura's statement about the girls who have richer vocabulary. In this case, boys can also have good score in English particularly in reading test and vocabulary test.

\section{Gender Difference in Linguistic Devices}

The analysis for showing the gender difference in linguistic devices was taken from the categorization of any expression produced by the participants into their linguistic devices. As explained in the literature review section, the linguistic devices which focused in the study were only focused on the sentence-initial conjunction, intensifier, aggressive, and assertive language as they are mostly occurred in both tasks.

In the monologue text, it was found that the male learner used sentence-initial conjunctions more often than the boy. The table. Below gives the examples of sentence-initial conjunctions constructed by the learners.

From the table, it can be seen that the boy produced five utterances with sentence-initial conjunctions while the girl only produced two utterances. Interestingly, both participant produced similar forms of conjunction; "and" and "after". Those conjunctions are mainly used in narrative text. The finding above is in the same agreement with Gascoigne (2002, p. 83) who affirmed that boys are more likely used conjunction when starting their speech. In this case, even though there were only few conjunctions mentioned by the male learner, he consistently began his utterance with the conjunctions.

Finally, the result of the dialogue text inferred that both students were already able to produce potential sentence-initial conjunctions as it is important to use them in order to connect one clause to

Table 3 Examples of Sentence-Initial Conjunction from the Participants' Utterances

\begin{tabular}{ll}
\hline Male & Female \\
\hline $\begin{array}{l}\text { And after that she feeds the bird, she feeds her } \\
\text { bird. }\end{array}$ & And ... feed the bird. \\
$\begin{array}{ll}\text { At ... after school at four o'clock she goes home } \\
\text { and plays with her play, plays with her friend in } \\
\text { the ... in the playground. }\end{array}$ & $\begin{array}{l}\text { After school finish he ... go .... goes to the park } \\
\text { and at nine o' clock she sleeps. }\end{array}$ \\
And in the morning she starts the whole thing \\
again.
\end{tabular}


another logically. However, the boy employed the initial conjunctions more than the girl did. The boy, with 15 conjunctions exceeded the girl's conjunction which had only 11 conjunctions.

Because the format of the conversation is similar with a peer debate, the participants consistently use two major words of conjunctions, "because" and "but".

In the case of intensifier, the male learner surprisingly surpassed the female learner did during the conversation even though the numbers are not considerably different. The boy made 7 intensifiers such as really, so, too, and very, while the girl produced 6 intensifiers. Here are some examples of the participants' utterances which included the intensifier.

From the findings above, there are both agreement and argument of the theory from Gascoigne (2002:83) which explained that the boys use sentence-initial conjunctions more often than the girls, yet the girls tended to produced more intensifiers than the boys. It is true that the male participant used more sentence-initial conjunctions than the girl. However, during the conversation, the boy also produced intensifiers more often than the girl. In fact, to give more intensive feelings to the interlocutor, the boy did not hesitate to repeat the intensifiers and followed by the verbs or adjectives. Therefore, the boy's utterances were considered more aggressive and assertive than the girl's.

All the results of gender difference of young learners supports the earlier study of Gallego (2012) who stated that the EFL young learners have similar behavior in lexical learning. In this case, both male and female learners showed insignificant differences in producing the language. Next, the previous study from Shakouri (2012) is also suitable to draw the final result of the present study. Both participants showed their own language abilities and strategies to make their interlocutor get their message. The girl with her politeness tried to make simple utterances so that her hearer would understand what she said, while the boy with his talkativeness tried his best to describe everything as clear as possible with extending his sentences.

Table 4 The Participants' Utterance Included the Sentence-Initial Conjunctions

\begin{tabular}{ll}
\hline Male & Female \\
\hline Because girls are more inclusive. & Because male sometimes do ... does discusss- \\
& ing thing in public, while female does the same \\
but in private time, not really public. \\
But , if we wear something else than we ...
\end{tabular}

Table 5 The Participants' Utterances Included the Intensifiers

\begin{tabular}{|c|c|}
\hline Male & Female \\
\hline Because Purple is so strange. & But boys are so so weird. \\
\hline $\begin{array}{l}\text { Female are too inclusive and they like, really really like } \\
\text { to chat because they are too chatty. }\end{array}$ & $\begin{array}{l}\text { Oooh. (laugh) because Matthew is so } \\
\text { weird and there ... }\end{array}$ \\
\hline
\end{tabular}


Lastly, when people thought that it is females who talk a lot in many spoken situation, the study provided different view of the gender difference in the case of young learners. Indeed, it supported Ellis (1994) statement that there is nothing conclusive of gender difference when it comes to the achievement, attitude, and strategy of producing the language.

\section{CONCLUSION}

To be concluded, from both dialogue and monologue texts, the male participant produced more words and utterances than the female participant did, which proves that boys can also talk a lot using foreign language during the interaction or telling a story. Next, the boy also created more sentence-initial conjunctions than girl in both situations. It perhaps become the reason why the boy's talk was smother and more understandable than the girl's talk. Furthermore, to intensify their opinion, both participant applied intensifier in almost equal numbers, the boy produced one more intensifiers than the girl. It happened mostly during the conversation time. Lastly, in the term of vocabulary knowledge, the boy indeed surpassed the girl when describing something in detail. It occurred commonly in telling the story task in which the boy described every activity as descriptive as possible.

As the study only covered several areas of language proficiency, it would be much contentious for the further study to have a wider area of language proficiency so that the comparison of gender would be much deeper and more acceptable. Another consideration for the further gender difference study is related with the data source and the time of collecting the data. The bigger the number of the participants and the longer the data collecting time will obviously extend the results of the study, and thus, will give a better conclusion.

\section{REFERENCES}

Aslan, O. (2009). The Role of Gender and Language Learning Strategies in Learning English. Unpublished Master's thesis.

Coates, J. (1997). Language and Gender: A Reader. Massachusetts: Blackwell Publisher Inc.

Edelenbos, M., \& Vinjé, M.P. (2000). The Assessment of A Foreign Language at the End of Primary (Elementary) Education. Language Testing. 17(2), 144-162. https://doi. org/10.1177/026553220001700203.

Ellis, R. (1994). The Study of Second Language Acquisition. Oxford: Oxford University Press.

Gallego, N.T. (2012). Vocabulary Knowledge Development and Gender Differences in A Second Language. ELIA. 12. 45-75. http://institucional.us.es/revistas/elia/12/art_3. pdf.

Gascoigne, C. (2002). The Role of Gender In L2 Interaction: Socialization Via L2 Materials. Encuentro Revista de Investigación e Innovación en la Clase de idi, 13(14), 81- 89. https://dialnet. u n i r o ja.es / s e r v le t / articulo? codigo $=2320267$.

Holmes, J. (2001). An Introduction to Sociolinguistics. London: Longman.

Jiménez, R.M. (2003). Sex Differences in L2 Vocabulary Learning Strategies. International Journal of Applied Lin- 
guistics. 13(1). Pp. 54-77. https:// doi.org/10.1111/1473-4192.00037.

Jiménez, R.M., \& Ojeda, J. (2009). Girls' and Boys' Lexical Availability in EFL. International Journal of Applied Linguistics, 158, 57-76. https://benjamins.com/catalog/itl.158.03jim.

Nation, P. (1984). Vocabulary Lists. Wellington: Victory University of Wellington, English Language Institute.

Piasecka, L. (2010). Gender Differences in L1 and L2 Reading. In J. Arabski \& A. Wojtaszek, Neurolinguistic and Psycholinguistic Perspectives on SLA (pp. 145-158). Toronto: Multilingual Matters.

Robin, R.T. (1975). Language and Woman's Place: Text and Commentaries. Oxford: Oxford University Press.

Shakouri, N. (2012). Revisiting Age and Gender Influence in Second Language Acquisition. Advances in Eng- lish Linguistics. 1(1), 1-6. https:// www.researchgate.net/publication/311439970_Revisiting_Age_ and_Gender_Influence_in_Second_ Language_Acquisition.

Tannen, D. (2007). You Just Don't Understand: Women and Men in Conversation. New York: Harper Collins Publisher.

West, C. \& Zimmerman, D.H. (1987). Doing Gender. Gender and Society. 1(2), 125-151: Sage Publication Inc. http://dx.doi.org/10.1177/089124 3287001002002.

Young, D. J. \& Oxford, R. (1997). A Gender-Related Analysis of Strategies Used to Process Written Input In The Native Language And A Foreign Language. Applied Language Learning. 8. pp. 43-73. https://eric. ed.gov/?id=EJ552194. 